\title{
Integrated Water Level Control System Using Fuzzy Logic
}

\author{
Akhmad Musafa ${ }^{1}$, Riyanto Wibisono ${ }^{2}$ \\ \{akhmad.musafa@budiluhur.ac.id ${ }^{1}$ \} \\ Department of Electrical Engineering, Universitas Budi Luhur, J1. Ciledug Raya, Jakarta, Indonesia ${ }^{1,2}$
}

\begin{abstract}
This paper presented the design of fuzzy logic control system to control water level on two water gates in an integrated manner. The system was designed on a prototype scale, which consists of a water gate and a control system part. The control system used two fuzzy logic controllers. The input of fuzzy logic controller was error signal and water level delta error, while the control output was the active time of the water gate motor (between 0-2 seconds) to adjust the opening size of the sluice gate. The quantities of inputs and outputs were grouped into five membership functions, with the defuzzification process using the Centre of Area (COA) method. The test results showed that the water level on the water gate 1 could reach a reference value of $10 \mathrm{~cm}$ with an initial level of $0 \mathrm{~cm}$ in 90 seconds, with the opening of the water gate 1 at $10 \%$ condition and the water gate 2 at $0 \%$ condition. For the water gate 2, the system response could reach the reference value within 340 seconds with the sluice gate of the water gate 2 up to $10 \%$ and the gate 1 reached $0 \%$. The system could run on the water gate 1 and on the water gate 2 , although there was a disturbance.
\end{abstract}

Keywords: Water level control, Water gate, Integrated, Fuzzy logic.

\section{Introduction}

Water level control at river gates is done by arranging the width of water gates. The control of water gate opening are made so that the water level upstream (before) of the water gate is maintained at the desired level, and the flow of water coming out of the water gate is also maintained. This aims to prevent the overflow of water from the river to the area around (river) river that can lead to flooding.

In most of the existing water gates, the process for increasing or reducing the sluice gate is done manually. Various studies have been conducted regarding the automatic of water level control at the sluice gate. Researches related to water level detection method on dam to prevent flooding has also been done, one of them by using image processing [1].

In the journal Alfatah (2016) was discussed about the automatic open-close system at the dam water gate to adjust the Arduinobased water level. The system is designed to detect changes in water levels, in input or output of rivers and also dams [2].

In addition, the research on the use of fuzzy logic algorithm for water level control had also been done, as in Dharamniwas, Aziz, Redhu, and Gupta (2012) that discussing fluid level control techniques using logic fuzzy [3]. In addition there are also papers presented by Farooq, Rafiq, F., Abbas, G., and Asad, (2016) and Mushtaq, Tayyaba, and Ashraf(2014)on fluid level control systems with fuzzy logic and simulation with Matlab [4], [5]. 
More specifically, the use of fuzzy logic on water level controls at sluices or dams had also been done. As in the paper M. Abbas, M. Saleem Khan (2011) that described the construction design of hydro-power DAM control using fuzzy logic. In this paper, the input of fuzzy logic controller is water level and flow rate, and the output is out-flow valve and opening of drain valve. Each input and output mapping in five triangular membership function, and deffuzification use center of average (C.O.A) method. The proposed design is verified using Matlab simulation. Simulation result show the drain valve control output can be utilized further for land irrigation according to the need [6].

While on paper Kusuma and Kurniawan(2016)it was explained about fuzzy logic gate control on the dam system. Ultrasonic sensor as the input of the system to be processed on the microcontroller and DC motor as the output of the system that will move the floodgates on the dam. At the opening of the water gate by DC motor with the output value of fuzzy logic at test 1 resulted in high value of the flood gate with an average of $0.936 \mathrm{~cm}$, the second test resulted in a high-value water gate with an average of $1.716 \mathrm{~cm}$, and on test 3 produced a high-value water gate with an average of $3.02 \mathrm{~cm}$ [7].

From the reference paper as described above, the water gate control is done in one condition which is the open-close water gate. Based on those above, in this paper, the design of water level control system on two water gates is integrated based on fuzzy logic.

\section{System Design}

The block diagram design of the level control system on two water gates is shown in Figure 1. The system design done is the design of the water gate system prototype (Figure 2) and the design of the control system.

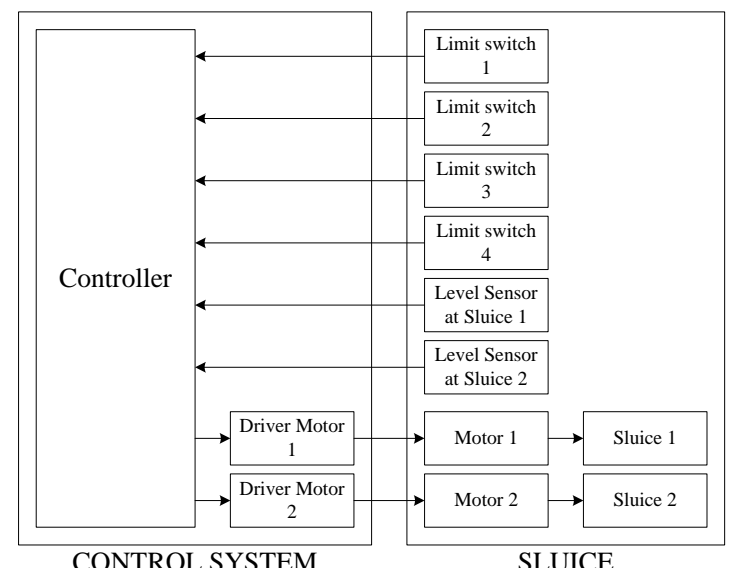

Fig. 1. Block diagram of a level control system on two integrated water gates. 


\subsection{Prototype Design}

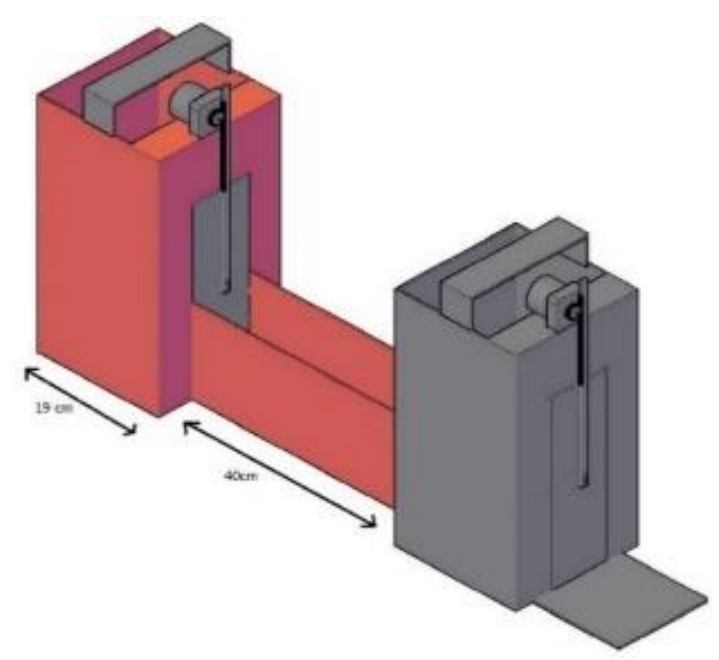

Fig. 2. The prototype design of the water gate system.

In the prototype design of water gate, there consists of two water gates (water gate 1 and water gate 2), the engine of the open-close door (motor 1 and motor 2), the level sensor at the water gate 1 and the level sensor at the water gate 2using the ultrasonic sensor HC-SR04 (Figure 3), and 4 switch limits for detecting the openings position of the water gate. While on the controller, there consists of a series of controllers using Arduino Mega2560 module (Figure 4) and motor driver circuit with L298 module (Figure 5).

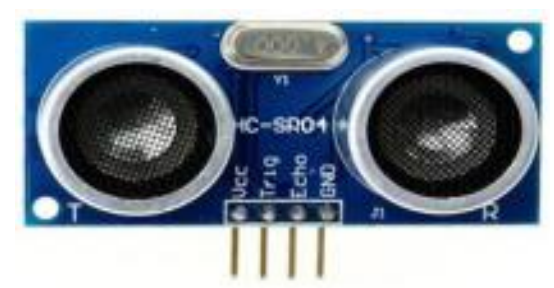

(a)

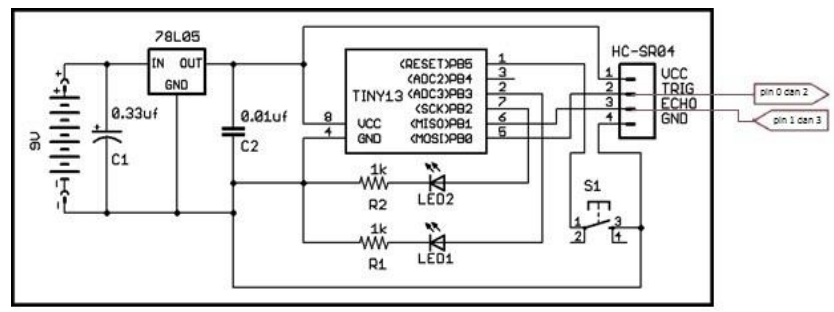

(b)

Fig. 3. Water level sensors (a) Ultrasonic sensor HC-SR04 series, (b) Schematic diagram of HC-SR04 series. 


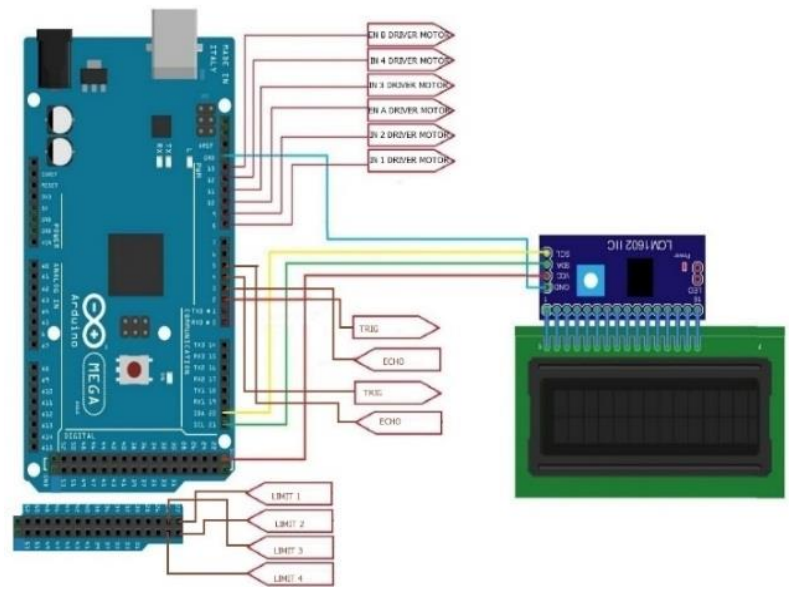

Fig. 4. The series of system controllers.

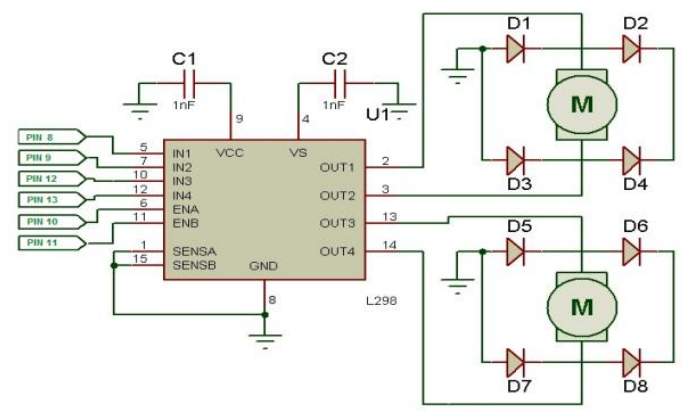

Fig. 5. Motor driver circuit.

\subsection{Fuzzy Logic Control System Design}

The Fuzzy Logic Controller is a controller which in the process uses the approach of thinking, experience, and human knowledge, without having to model plants in complex mathematical equations. In general, the system configuration with fuzzy logic controller is shown in Figure 6.

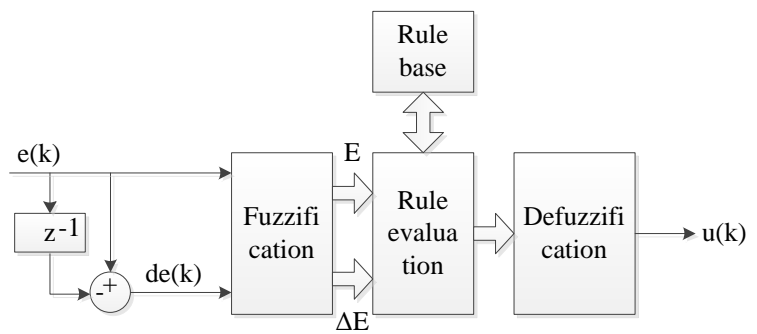

Fig. 6. Block diagram of the FLC system. 
One of the fuzzy inference systems that can be used is Mamdani method (Max-Min Method). This method divides the fuzzy process in four stages, namely the formation of fuzzy set (fuzzification), application of implication function, rule composition (rule evaluation), and affirmation (defuzzification). Figure 7 shows a fuzzy logic controller implementation for an integrated water level control system on two water gates.

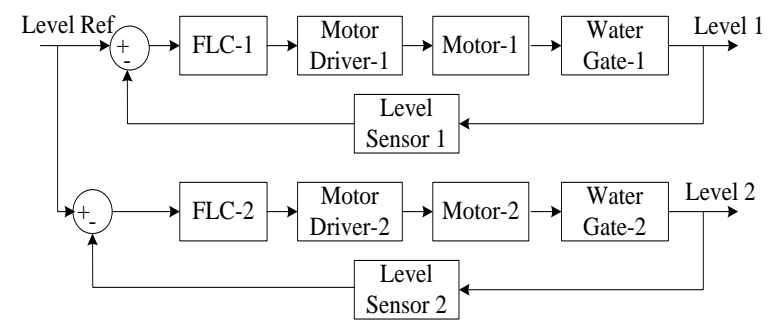

Fig. 7. Implementation of fuzzy logic controllers for water level control systems on two integrated water gates.

The fuzzy logic controller is designed using Mamdani method, the control input is the error signal and the water level delta error. In the fuzzification stage, each input is grouped into five membership functions. In this stage there is a quantization process, i.e. converting error and delta error signals to quantized signals, with the quantization level shown in Table 1. Similarly for output, the membership functions are expressed in discrete functions as shown in Table 2.

Table 1. Quantization level of error and delta error.

\begin{tabular}{cccc}
\hline Error & Qerror & d_error & Qd_error \\
\hline$\geq 20$ & 9 & $\geq 2$ & 9 \\
\hline $18 \leq \ldots<20$ & 8 & $1.8 \leq \ldots<2$ & 8 \\
\hline $16 \leq \ldots<18$ & 7 & $1.6 \leq \ldots<1.8$ & 7 \\
\hline $14 \leq \ldots<16$ & 6 & $1.4 \leq \ldots<1.6$ & 6 \\
\hline $12 \leq \ldots<14$ & 5 & $1.2 \leq \ldots<1.4$ & 5 \\
\hline $10 \leq \ldots<12$ & 4 & $1 \leq \ldots<1.2$ & 4 \\
\hline $8 \leq \ldots<10$ & 3 & $0.8 \leq \ldots<1$ & 3 \\
\hline $6 \leq \ldots<8$ & 2 & $0.6 \leq \ldots<0.8$ & 2 \\
\hline $2 \leq \ldots<6$ & 1 & $0.2 \leq \ldots<0.6$ & 1 \\
\hline $0 \leq \ldots<2$ & 0 & $0 \leq \ldots<0.2$ & 0 \\
\hline$-2 \leq \ldots<0$ & -1 & $-0.2 \leq \ldots<0$ & -1 \\
\hline$-6 \leq \ldots<-2$ & -2 & $-0.6 \leq \ldots<-0.2$ & -2 \\
\hline$-8 \leq \ldots<-6$ & -3 & $-0.8 \leq \ldots<-0.6$ & -3 \\
\hline$-10 \leq \ldots<-8$ & -4 & $-1 \leq \ldots<-0.8$ & -4 \\
\hline$-12 \leq \ldots<-10$ & -5 & $-1.2 \leq \ldots<-1$ & -5 \\
\hline$-14 \leq \ldots<-12$ & -6 & $-1.4 \leq \ldots<-1.2$ & -6 \\
\hline & & &
\end{tabular}




\begin{tabular}{cccc}
\hline$-16 \leq \ldots<-14$ & -7 & $-1.6 \leq \ldots<-1.4$ & -7 \\
\hline$-18 \leq \ldots<-16$ & -8 & $-1.8 \leq \ldots<-1.6$ & -8 \\
\hline$<-18$ & -9 & $<-1.8$ & -9 \\
\hline
\end{tabular}

Table 2. Definition of input membership function.

\begin{tabular}{|c|c|c|c|c|c|c|c|c|c|c|c|c|c|c|c|c|c|c|c|}
\hline & -20 & -18 & -16 & -14 & -12 & -10 & -8 & -6 & -2 & 0 & 2 & 6 & 8 & 10 & 12 & 14 & 16 & 18 & 20 \\
\hline PB & 0 & 0 & 0 & 0 & 0 & 0 & 0 & 0 & 0 & 0 & 0 & 0 & 0 & 0 & 0 & 0.5 & 1 & 1 & 1 \\
\hline PK & 0 & 0 & 0 & 0 & 0 & 0 & 0 & 0 & 0 & 0 & 0 & 0.5 & 0.6 & 1 & 0.6 & 0.5 & 0.3 & 0 & 0 \\
\hline AZ & 0 & 0 & 0 & 0 & 0 & 0 & 0 & 0.3 & 0.7 & 1 & 0.7 & 0.3 & 0 & 0 & 0 & 0 & 0 & 0 & 0 \\
\hline NK & 0 & 0 & 0.3 & 0.5 & 0.6 & 1 & 0.6 & 0.5 & 0 & 0 & 0 & 0 & 0 & 0 & 0 & 0 & 0 & 0 & 0 \\
\hline NB & 1 & 1 & 1 & 0.5 & 0 & 0 & 0 & 0 & 0 & 0 & 0 & 0 & 0 & 0 & 0 & 0 & 0 & 0 & 0 \\
\hline
\end{tabular}

Based on the quantitation process shown in Table 1 and Table 2, the form of the membership function of the input and output of fuzzy logic controller is shown in Figure 8, Figure 9, and Figure 10.

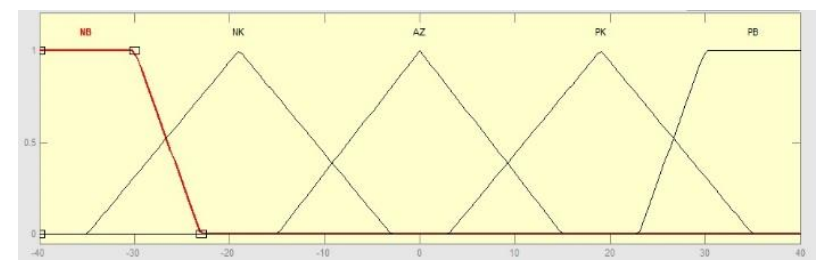

Fig. 8. Fuzzification of input error.

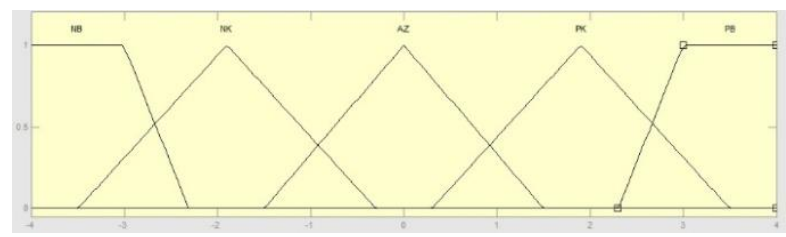

Fig. 9. Fuzzification of input delta error

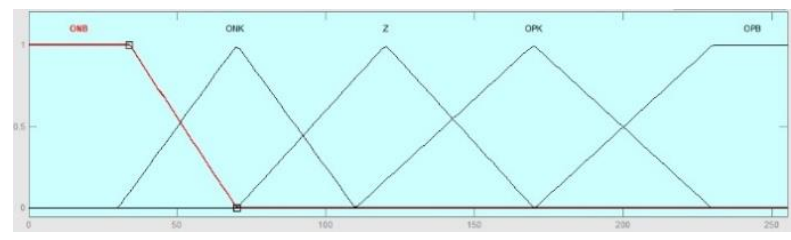

Fig. 10. Fuzzification of output.

With both inputs and each input grouped into five membership functions, then the number of fuzzy rules to be applied is as many as 25 rules, as shown in Table 3. 
Table 3. Fuzzy rules.

\begin{tabular}{|c|c|c|c|c|c|c|}
\hline \multirow{2}{*}{\multicolumn{2}{|c|}{$\begin{array}{l}\text { Operator } \\
\text { AND }\end{array}$}} & \multicolumn{5}{|c|}{ Error } \\
\hline & & \multirow{2}{*}{$\frac{\mathrm{NB}}{\mathrm{NB}}$} & \multirow{2}{*}{$\begin{array}{l}\mathrm{NS} \\
\mathrm{NS} \\
\end{array}$} & \multirow{2}{*}{$\frac{\mathrm{Z}}{\mathrm{AZ}}$} & \multirow{2}{*}{$\begin{array}{l}\mathrm{PS} \\
\mathrm{PB}\end{array}$} & \multirow{2}{*}{$\frac{\mathrm{PB}}{\mathrm{NB}}$} \\
\hline \multirow{5}{*}{ 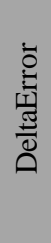 } & $\mathrm{NB}$ & & & & & \\
\hline & NS & NS & NS & NS & NS & NS \\
\hline & $\mathrm{Z}$ & $\mathrm{AZ}$ & $\mathrm{AZ}$ & $\mathrm{AZ}$ & $\mathrm{AZ}$ & $\mathrm{AZ}$ \\
\hline & PS & PS & PS & PS & PS & PS \\
\hline & PB & PB & PB & PB & PB & PB \\
\hline
\end{tabular}

The third stage is the defuzzification process. In this research, defuzzification process used conducted by using Center of Area (COA) method. This method is articulated by equation 1 [4] as follows:

$$
Z_{o}=\frac{\sum_{i=1}^{n} Z_{i} \mu_{\text {out }}\left(Z_{i}\right)}{\sum_{i=1}^{n} \mu_{o u t}\left(Z_{i}\right)}
$$

where $Z_{o}$ is the value of crisp value, which is the motor's active time span $(0-2$ seconds), $\mathrm{n}$ is the quantization level $(\mathrm{i}=1,2, \ldots, \mathrm{n}), \mathrm{Z}_{\mathrm{i}}$ is $\mathrm{i}$ element, and $\mu_{\text {out }}(\mathrm{Zi})$ states the stage membership of elements in i fuzzy set. Then, there designed algorithm program to be embedded in microcontroller in Arduino module. The program algorithm consists of the main program and the fuzzy logic controller program, with the flowchart shown in Figure 11 and Figure 12.

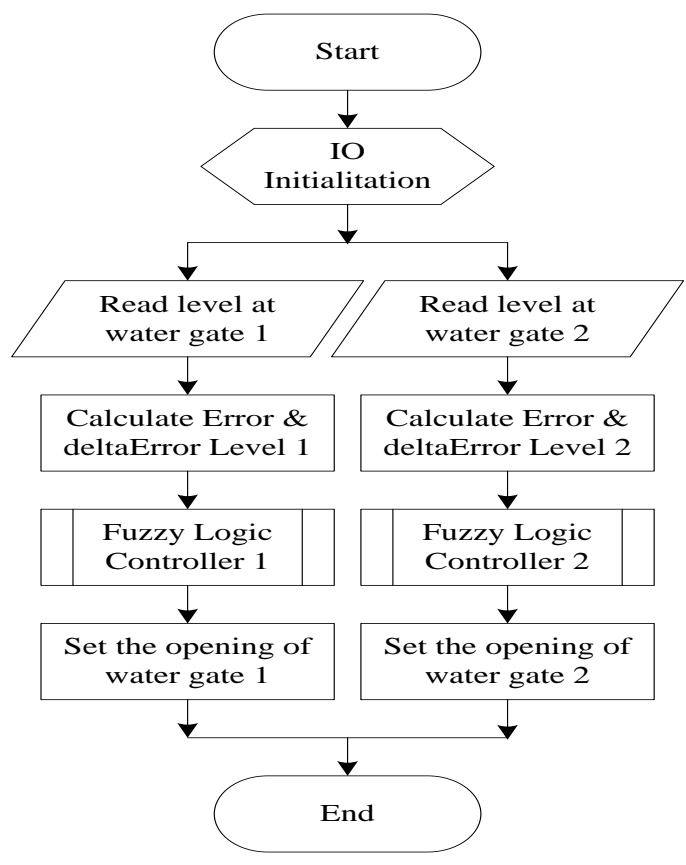

Fig. 11. Algorithm main program. 


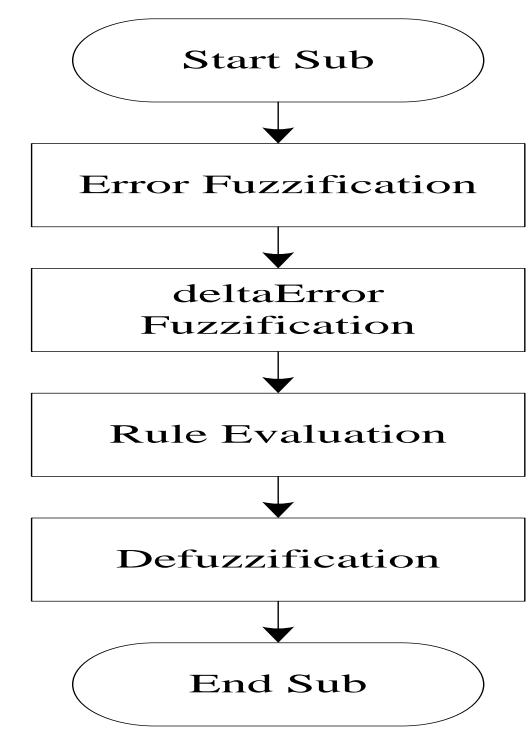

Fig. 12. Algorithm of fuzzy logic controller sub-program.

\section{Result and Discussion}

Figure 13 shows the prototype of the system design. System test is done by giving the reference level of $10 \mathrm{~cm}$ and the initial level $0 \mathrm{~cm}$. The test results are presented in Table 4 with the system response shown in Figure 14 and Figure 15.

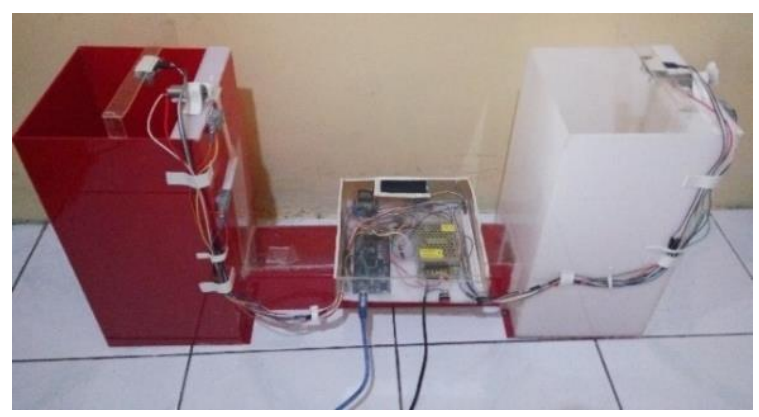

Fig. 13. Prototype system. 
Table 4. System test results with reference level $10 \mathrm{~cm}$ and initial level $0 \mathrm{~cm}$.

\begin{tabular}{|c|c|c|c|c|c|c|}
\hline No & $\begin{array}{c}\text { SP } \\
(\mathrm{cm})\end{array}$ & $\begin{array}{l}\text { Water } \\
\text { Level } \\
1(\mathrm{~cm})\end{array}$ & $\begin{array}{l}\text { Water } \\
\text { Level } \\
2(\mathrm{~cm})\end{array}$ & $\begin{array}{c}\text { Water } \\
\text { Gate1 } \\
(\%)\end{array}$ & $\begin{array}{c}\text { Water } \\
\text { Gate2 } \\
(\%)\end{array}$ & $\begin{array}{l}\text { Test } \\
\text { Time } \\
(\mathrm{sec})\end{array}$ \\
\hline 1 & 10 & 12 & 5 & 0 & 0 & 0 \\
\hline 2 & 10 & 12 & 5 & 0 & 0 & 5 \\
\hline 3 & 10 & 8 & 8 & 20 & 0 & 10 \\
\hline 4 & 10 & 8 & 8 & 20 & 0 & 15 \\
\hline 5 & 10 & 8 & 8 & 20 & 0 & 20 \\
\hline 6 & 10 & 7 & 7 & 20 & 0 & 25 \\
\hline 7 & 10 & 7 & 7 & 20 & 0 & 30 \\
\hline 8 & 10 & 7 & 7 & 20 & 0 & 35 \\
\hline 9 & 10 & 7 & 7 & 20 & 0 & 40 \\
\hline 10 & 10 & 7 & 7 & 20 & 0 & 45 \\
\hline 11 & 10 & 7 & 7 & 20 & 0 & 50 \\
\hline 12 & 10 & 7 & 7 & 20 & 0 & 55 \\
\hline 13 & 10 & 7 & 7 & 20 & 0 & 60 \\
\hline 14 & 10 & 7 & 7 & 20 & 0 & 65 \\
\hline 15 & 10 & 7 & 7 & 20 & 0 & 70 \\
\hline 16 & 10 & 8 & 8 & 20 & 0 & 75 \\
\hline 17 & 10 & 8 & 8 & 20 & 0 & 80 \\
\hline 18 & 10 & 8 & 8 & 20 & 0 & 85 \\
\hline 19 & 10 & 8 & 8 & 20 & 0 & 90 \\
\hline 20 & 10 & 8 & 8 & 20 & 0 & 95 \\
\hline 21 & 10 & 9 & 9 & 20 & 0 & 100 \\
\hline 22 & 10 & 9 & 9 & 20 & 0 & 105 \\
\hline 23 & 10 & 9 & 9 & 20 & 0 & 110 \\
\hline 24 & 10 & 9 & 9 & 20 & 0 & 115 \\
\hline 25 & 10 & 10 & 10 & 20 & 0 & 120 \\
\hline 26 & 10 & 10 & 10 & 20 & 0 & 130 \\
\hline 27 & 10 & 10 & 10 & 20 & 0 & 140 \\
\hline 28 & 10 & 10 & 10 & 20 & 0 & 150 \\
\hline 29 & 10 & 11 & 11 & 20 & 0 & 160 \\
\hline 30 & 10 & 11 & 11 & 20 & 0 & 170 \\
\hline 31 & 10 & 8 & 8 & 40 & 20 & 180 \\
\hline 32 & 10 & 8 & 8 & 40 & 20 & 190 \\
\hline 33 & 10 & 7 & 7 & 40 & 20 & 200 \\
\hline 34 & 10 & 7 & 7 & 40 & 20 & 210 \\
\hline 35 & 10 & 6 & 6 & 40 & 20 & 220 \\
\hline 36 & 10 & 6 & 6 & 40 & 20 & 230 \\
\hline 37 & 10 & 5 & 5 & 40 & 20 & 240 \\
\hline 38 & 10 & 5 & 5 & 40 & 20 & 250 \\
\hline 39 & 10 & 4 & 4 & 40 & 20 & 260 \\
\hline 40 & 10 & 4 & 4 & 40 & 20 & 270 \\
\hline 41 & 10 & 3 & 3 & 20 & 20 & 280 \\
\hline 42 & 10 & 3 & 3 & 20 & 0 & 290 \\
\hline 43 & 10 & 3 & 3 & 20 & 0 & 300 \\
\hline 44 & 10 & 4 & 3 & 0 & 0 & 310 \\
\hline 45 & 10 & 4 & 3 & 0 & 0 & 320 \\
\hline 46 & 10 & 5 & 4 & 0 & 0 & 330 \\
\hline 47 & 10 & 6 & 4 & 0 & 0 & 340 \\
\hline 48 & 10 & 6 & 4 & 0 & 0 & 350 \\
\hline
\end{tabular}




\begin{tabular}{ccccccc}
\hline 49 & 10 & 7 & 4 & 0 & 0 & 360 \\
50 & 10 & 7 & 4 & 0 & 0 & 370 \\
51 & 10 & 8 & 4 & 0 & 0 & 380 \\
52 & 10 & 8 & 4 & 0 & 0 & 390 \\
53 & 10 & 9 & 5 & 0 & 0 & 400 \\
54 & 10 & 9 & 5 & 0 & 0 & 410 \\
55 & 10 & 10 & 5 & 0 & 0 & 420 \\
56 & 10 & 10 & 5 & 0 & 0 & 430 \\
57 & 10 & 11 & 5 & 0 & 0 & 440 \\
58 & 10 & 8 & 8 & 0 & 0 & 450 \\
59 & 10 & 8 & 8 & 0 & 0 & 460 \\
60 & 10 & 7 & 7 & 0 & 0 & 470 \\
61 & 10 & 7 & 7 & 0 & 0 & 480 \\
62 & 10 & 7 & 7 & 0 & 0 & 490 \\
\hline
\end{tabular}

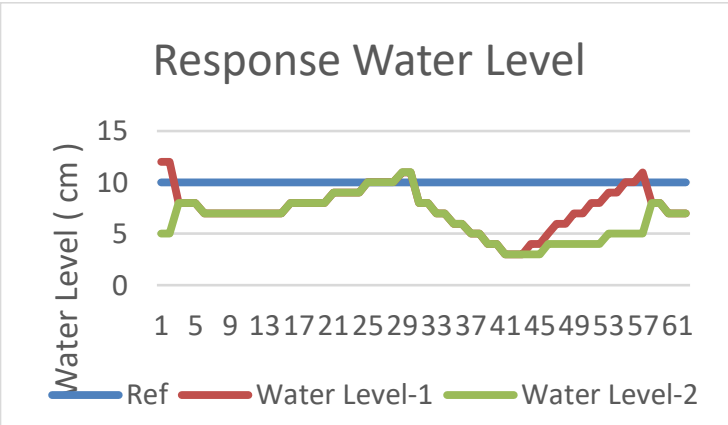

Fig. 14. Graph of water level response at water gate 1 and water gate 2 with reference level $10 \mathrm{~cm}$ and initial level $0 \mathrm{~cm}$.

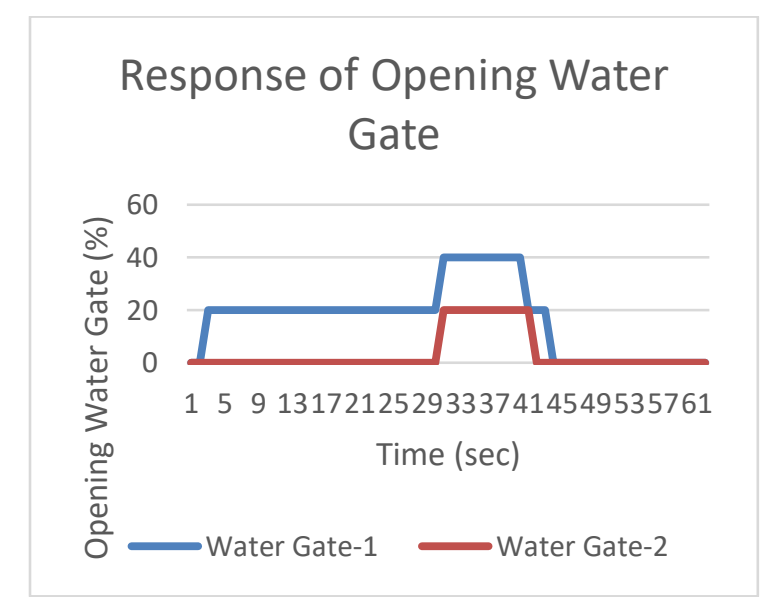

Fig. 15. Graph of the response of water gate 1 and water gate 2 when the reference level $10 \mathrm{~cm}$ and initial level $0 \mathrm{~cm}$. 
From the test results on the water level control system device, it can be known that the system time in steady state (ts) on the water gate 1 for 120 seconds to reach set point $10 \mathrm{~cm}$. Steady state lasted for 30 seconds with the water gate open up to $40 \%$ and at gate 2 reached up to $20 \%$. The system can run on the water gate 1 and on the water gate 2 perfectly despite disturbance occurs.

The next test is the value of the reference level of $10 \mathrm{~cm}$ and the initial water level on the water gate 1 at $11 \mathrm{~cm}$ position and the water level on the water gate 2 at position $15 \mathrm{~cm}$. The result of the system test is shown in Table 5 with the system response shown in Figure 16 and Figure 17.

Table 5. System test results with reference level $10 \mathrm{~cm}$ and initial level $11 \mathrm{~cm}$.

\begin{tabular}{ccccccc}
\hline No & $\begin{array}{c}\text { SP } \\
(\mathrm{cm})\end{array}$ & $\begin{array}{c}\text { Water } \\
\text { Level } \\
1(\mathrm{~cm})\end{array}$ & $\begin{array}{c}\text { Water } \\
\text { Level } \\
2(\mathrm{~cm})\end{array}$ & $\begin{array}{c}\text { Water } \\
\text { gate } 1 \\
(\%)\end{array}$ & $\begin{array}{c}\text { Water } \\
\text { gate } 2 \\
(\%)\end{array}$ & $\begin{array}{c}\text { Test } \\
\text { Time } \\
(\mathrm{sec})\end{array}$ \\
\hline 1 & 10 & 11 & 15 & 0 & 0 & 0 \\
2 & 10 & 11 & 15 & 20 & 40 & 5 \\
3 & 10 & 10 & 14 & 20 & 40 & 10 \\
4 & 10 & 10 & 13 & 20 & 40 & 15 \\
5 & 10 & 9 & 12 & 20 & 40 & 20 \\
6 & 10 & 9 & 11 & 20 & 40 & 25 \\
7 & 10 & 9 & 10 & 20 & 40 & 30 \\
8 & 10 & 8 & 9 & 20 & 40 & 35 \\
9 & 10 & 8 & 8 & 20 & 40 & 40 \\
10 & 10 & 7 & 8 & 20 & 40 & 45 \\
11 & 10 & 7 & 7 & 20 & 40 & 50 \\
12 & 10 & 6 & 7 & 20 & 40 & 55 \\
13 & 10 & 6 & 6 & 20 & 40 & 60 \\
14 & 10 & 5 & 6 & 20 & 40 & 65 \\
15 & 10 & 5 & 5 & 20 & 40 & 70 \\
16 & 10 & 4 & 5 & 20 & 40 & 75 \\
17 & 10 & 4 & 4 & 20 & 40 & 80 \\
18 & 10 & 3 & 4 & 0 & 20 & 85 \\
19 & 10 & 3 & 3 & 0 & 20 & 90 \\
20 & 10 & 5 & 3 & 0 & 20 & 95 \\
21 & 10 & 5 & 2 & 0 & 20 & 100 \\
22 & 10 & 6 & 2 & 0 & 0 & 105 \\
23 & 10 & 6 & 3 & 0 & 0 & 110 \\
24 & 10 & 7 & 3 & 0 & 0 & 115 \\
25 & 10 & 7 & 3 & 0 & 0 & 120 \\
26 & 10 & 8 & 3 & 0 & 0 & 125 \\
27 & 10 & 8 & 4 & 0 & 0 & 130 \\
28 & 10 & 9 & 4 & 0 & 0 & 135 \\
29 & 10 & 9 & 4 & 0 & 0 & 140 \\
30 & 10 & 10 & 4 & 0 & 0 & 150 \\
31 & 10 & 10 & 4 & 0 & 0 & 160 \\
32 & 10 & 10 & 4 & 0 & 0 & 170 \\
33 & 10 & 10 & 4 & 0 & 0 & 180 \\
34 & 10 & 10 & 4 & 0 & 0 & 190 \\
35 & 10 & 11 & 4 & 0 & 0 & 200 \\
36 & 10 & 11 & 4 & 20 & 0 & 210 \\
37 & 10 & 7 & 7 & 20 & 0 & 220 \\
\hline & & & & & &
\end{tabular}




\begin{tabular}{|c|c|c|c|c|c|c|}
\hline 38 & 10 & 7 & 7 & 20 & 0 & 230 \\
\hline 39 & 10 & 7 & 7 & 20 & 0 & 240 \\
\hline 40 & 10 & 7 & 7 & 20 & 0 & 250 \\
\hline 41 & 10 & 8 & 8 & 20 & 0 & 260 \\
\hline 42 & 10 & 8 & 8 & 20 & 0 & 270 \\
\hline 43 & 10 & 8 & 8 & 20 & 0 & 280 \\
\hline 44 & 10 & 8 & 8 & 20 & 0 & 290 \\
\hline 45 & 10 & 9 & 8 & 20 & 0 & 300 \\
\hline 46 & 10 & 9 & 8 & 20 & 0 & 310 \\
\hline 47 & 10 & 9 & 9 & 20 & 0 & 320 \\
\hline 48 & 10 & 9 & 9 & 20 & 0 & 330 \\
\hline 49 & 10 & 10 & 9 & 20 & 0 & 340 \\
\hline 50 & 10 & 10 & 9 & 20 & 0 & 350 \\
\hline 51 & 10 & 10 & 10 & 20 & 0 & 360 \\
\hline 52 & 10 & 10 & 10 & 20 & 0 & 370 \\
\hline 53 & 10 & 11 & 10 & 20 & 0 & 380 \\
\hline 54 & 10 & 11 & 10 & 20 & 0 & 390 \\
\hline 55 & 10 & 12 & 11 & 20 & 0 & 400 \\
\hline 56 & 10 & 12 & 11 & 40 & 20 & 410 \\
\hline 57 & 10 & 11 & 10 & 40 & 20 & 420 \\
\hline 58 & 10 & 11 & 10 & 40 & 20 & 430 \\
\hline 59 & 10 & 10 & 9 & 40 & 20 & 440 \\
\hline 60 & 10 & 10 & 9 & 40 & 20 & 450 \\
\hline 61 & 10 & 9 & 8 & 40 & 20 & 460 \\
\hline 62 & 10 & 9 & 8 & 40 & 20 & 470 \\
\hline 63 & 10 & 8 & 7 & 40 & 20 & 480 \\
\hline 64 & 10 & 8 & 7 & 40 & 20 & 490 \\
\hline 65 & 10 & 7 & 6 & 40 & 20 & 500 \\
\hline 66 & 10 & 7 & 6 & 40 & 20 & 510 \\
\hline 67 & 10 & 6 & 5 & 40 & 20 & 520 \\
\hline 68 & 10 & 6 & 5 & 40 & 20 & 530 \\
\hline 69 & 10 & 5 & 4 & 40 & 20 & 540 \\
\hline 70 & 10 & 5 & 4 & 40 & 20 & 550 \\
\hline 71 & 10 & 4 & 3 & 40 & 0 & 560 \\
\hline 72 & 10 & 4 & 3 & 40 & 0 & 570 \\
\hline 73 & 10 & 3 & 3 & 20 & 0 & 580 \\
\hline 74 & 10 & 3 & 3 & 20 & 0 & 590 \\
\hline 75 & 10 & 3 & 3 & 20 & 0 & 600 \\
\hline 76 & 10 & 3 & 3 & 0 & 0 & 610 \\
\hline 77 & 10 & 4 & 4 & 0 & 0 & 620 \\
\hline 78 & 10 & 4 & 4 & 0 & 0 & 630 \\
\hline 79 & 10 & 4 & 4 & 0 & 0 & 640 \\
\hline 80 & 10 & 4 & 4 & 0 & 0 & 650 \\
\hline 81 & 10 & 4 & 4 & 0 & 0 & 660 \\
\hline
\end{tabular}




\section{Response of Water Level}

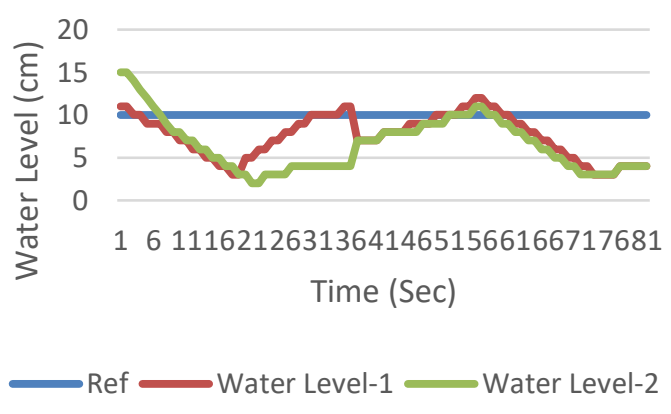

Fig. 16. Graph of water level response at water gate 1 and water gate 2 with reference level $10 \mathrm{~cm}$ and initial position level $11 \mathrm{~cm}$.

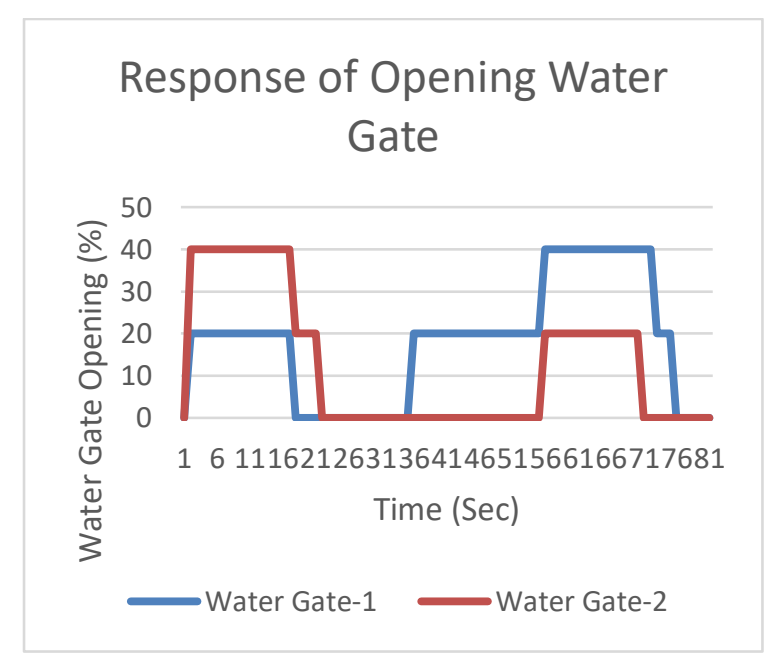

Fig. 17. Graph of the response of water gate 1 and water gate 2 when the reference level $10 \mathrm{~cm}$ and initial level $11 \mathrm{~cm}$.

From the test results, when it was given the reference level of $10 \mathrm{~cm}$ and the initial level of $11 \mathrm{~cm}$, it can be seen that the system response reached the steady state on the gate 1 within 150 seconds. The steady state lasted for 40 seconds with the opening of the water gate 1 up to $20 \%$ and the opening of the water gate 2 at $0 \%$. The system could run on the water gate 1 and on the water gate 2 perfectly despite any disturbance occurs. 


\section{Conclusion}

Based on the results of system testing, it is known that when given a reference level of 10 $\mathrm{cm}$ with an initial level of $0 \mathrm{~cm}$, on the gate 1 , the system was able to reach a reference value within 90 seconds. The steady state lasted for 20 seconds with the opening water gate at $10 \%$ and in water gate 2 at $0 \%$. For the water gate 2 , the system response could reach the reference value within 340 seconds. The steady state of the gate 2 lasted for 30 seconds with the opening gate 2 reached $10 \%$ and the water gate 1 at $0 \%$. The system could run on the water gate 1 and on the water gate 2 although there was a disturbance occurred.

\section{References}

[1]A. Riyanto, I., Musafa, "Image Processing-based Flood Detection for Online Flood Early Warning System,” IJJSS 2014 6th Indones. Jt. Sci. Symp., vol. ISSN 978-9, no. October 2014, p. C4, 2014.

[2]M. R. Alfatah, "Prototype Sistem Buka Tutup Otomatis Pada Pintu Air Bendungan untuk Mengatur Ketinggian Air Berbasis Arduino," Final Proj. Univ. Muhammadiyah Surakarta, 2016.

[3]Dharamniwas, A. Aziz, V. Redhu, and U. Gupta, "Liquid Level Control By Using Fuzzy Logic Controller,” Int. J. Adv. Eng. Technol., vol. 4, no. 1, pp. 537-549, 2012.

[4]U. Farooq, Rafiq, F., Abbas, G., Asad, “A Simplified Fuzzy Logic Liquid Level Control System,” J. Intell. Comput., vol. 7, no. 4, pp. 135-144, 2016.

[5]Z. Mushtaq, S. Tayyaba, and M. W. Ashraf, "Liquid Level Controlling by Fuzzy Logic Technique," Int. J. Innov. Sci. Res., vol. 12, no. 2, pp. 372-379, 2014.

[6]N. A. M. Abbas, M. Saleem Khan, "Fuzzy Logic Based Hydro-Electric Power Dam Control System," IJSER, vol. 2, no. 6, pp. 1-8, 2011.

[7]T. C. Kusuma and E. Kurniawan, "Design of Water DAM Control System Based on Fuzzy Logic," eProceeding Eng., vol. 3, no. 3, pp. 4023-4034, 2016. 